\title{
Ready Contents or Future Skills? A Comparative Study of Teacher Education in Thailand and Finland
}

\author{
Jutarat Vibulphol $^{1}$, Jyrki Loima ${ }^{1,2}$, Sornnate Areesophonpichet ${ }^{1}$ \& Chanita Rukspollmuang ${ }^{1}$ \\ ${ }^{1}$ Faculty of Education, Chulalongkorn University, Bangkok, Thailand \\ ${ }^{2}$ Faculty of Social Sciences and Business Studies, University of Eastern Finland, Joensuu, Finland \\ Correspondence: Jutarat Vibulphol, Faculty of Education, Chulalongkorn University, Phya Thai Road, \\ Patumwan, Bangkok, 10330, Thailand. Tel: 66-81-824-5585. E-mail: jutarat.v@chula.ac.th
}

Received: August 5, 2015

doi:10.5539/jel.v4n4p149
Accepted: September 21, $2015 \quad$ Online Published: November 9, 2015

URL: http://dx.doi.org/10.5539/jel.v4n4p149

\begin{abstract}
This study aimed to analyze the recently updated teacher education programmes in two universities in Finland and Thailand. The article reports the characteristics of the elementary and secondary school teacher education studies in the selected universities, and discusses the roles and significance of $21^{\text {st }}$ century skills and their modifications in these programmes. This kind of qualitative case comparison that focuses on modern skills and intercultural programmes is a new approach.

The methods were document analysis and questionnaire-based survey. Six teacher educators who had important roles in the recent programme updates, three from each university, were the survey informants.

The findings revealed that the policies and approaches to teacher education were different. While the Thai programmes focused more on courses, the Finns had a wider educational view. Second, research, skills and teaching practice were seen to be important, but the purposes were parted. Finally, as teachers' professional development tools, those will need further studies.
\end{abstract}

Keywords: teacher education, $21^{\text {st }}$ century skills, pre-service teacher training, skill-based education

\section{Introduction}

Standards for learning are now higher than they have ever been before, as citizens and workers need greater knowledge and skill to survive and succeed. Education is increasingly important to the success of both individuals and nations, and growing evidences have demonstrated that-among all educational resources - teacher's abilities are especially crucial contributors to students' learning (Darling-Hammond, 2006a, p. 1).

The purpose of this qualitative, comparative case study was to analyze the current elementary and secondary teacher education programmes in University of Helsinki (UHEL), Finland, and Chulalongkorn University (CU), Thailand, which were revised in 2013 and 2014 respectively (Department of Teacher Education, UHEL (TEd, UHEL), n.d.; Faculty of Education, CU (FoE, CU), n.d.). These two programmes were chosen since they present the academic mainstream of the teacher education in the countries concerned and the focuses in these would indicate the views about future teaching core competencies. This case study addressed both the "subject teacher" programmes, which prepare subject specialized teachers for secondary education and the "class teacher" programmes, which prepare teachers for elementary education.

The main emphasis of this research was on the modern skill-based teacher education since first, the $21^{\text {st }}$ century learning environments require skills that were not needed so much previously but are currently required and assessed all the time (Darling-Hammond, 2006a; Darling-Hammond \& Adamsson, 2014; Dede, 2010; Pearlman, 2010; see also Hämäläinen \& Välijärvi, 2008; Sinlarat et al., 2014). Furthermore, this kind of skill-based teacher education case comparison has never been done, especially for these recently (2013-2014) updated programmes. The previous UHEL programmes may have been analyzed in some aspects (e.g., Krzywacki, Maaranen, \& Lavonen, 2012) and literature that describes the teacher education system in each country may be found (e.g., Kansanen, 2008; Niemi, 2012b; Thongthew, 2014; Tirri, 2014); however, a study of the modern skill development in teacher education in Asia and Europe in the same paper has not been previously conducted. Commonly, independent articles addressing various teacher education systems have been published together as a 
collection, e.g., Darling-Hammond and Lieberman (2012) and Tan (2012). In addition, Finnish and Thai teacher education has not been studied together in any context even though they share some similarities. Regardless of the different higher education policies (MoE, TH, 2005; MoEC, FI, 2011), these case universities have designed similar pattern in their teacher education - both universities have 5 years of pre-service teacher education programmes and search for improved quality as main teacher education universities of their countries (TEd, UHEL, n.d.; FoE, CU, n.d.). In brief, this paper aims to find answers to the following research questions (RQs):

(1). What are the key characteristics of the teacher education studies at UHEL and CU?

(2). What are the roles and significance of $21^{\text {st }}$ century skills and their modifications in current teacher education programmes?

While teacher education in Finland has been constantly examined and found to be of a high quality and "distinctive" in a wider context (e.g., Kansanen, 2008; Krzywacki, Maaranen, \& Lavonen, 2012; Niemi, 2002, 2012a, 2012b, 2012c; Tirri, 2014; Toom, 2013). Thai teacher education has received minor attention in the international research field. Regardless of this tendency, skill-based descriptions could be found in the teacher education studies in both universities (TEd, UHEL, n.d.; FoE, CU, n.d.; cf. Darling-Hammond, 2010b; Dede, 2010; Niemi, 2012b; Tirri, 2014; Thongthew, 2014). Recent comparative studies on teacher education examining structures, competencies and importance of education and research skills in teacher education programmes have been conducted in other contexts. To name a few, Niemi (2012b) discussed the competencies enhanced in Finnish teacher education, Munthe and Rogne (2015) contributed on the research skills that undergraduate studies in teacher education in Norway may develop, and Krzywacki, Maaranen and Lavonen (2012) focused on the enhancement of pedagogical thinking in Finnish teacher education. In addition to these approaches and contributions, the comparison of the "drivers" for skill development in the updated programmes in the two universities also was one of the focuses of this paper.

These two universities of Finland and Thailand offer Bachelor's and Master's studies for future teachers and require their candidates to have completed K-12 or high school studies (for full descriptions, see TEd, UHEL, n.d.; FoE, $\mathrm{CU}$, n.d.). Teacher education studies at UHEL do not have many subject matter courses but at $\mathrm{CU}$ they do. In addition to previously mentioned meanings, this research will help to locate both universities to a modern globalizing learning and skill-based teacher education think-tank "landscape" in terms of being national key education promoters (cf. Goodwin, 2010; Munthe \& Rogne, 2015; Niemi, 2012c). Subsequently, the study outcomes will provide an opportunity to update the teacher education curricula and examine further, what kind of new approaches would be needed to improve the teacher education programmes in the changing global and local contexts. In terms of research priorities, the main role of educational policies and research should be on the analysis of the learning (results) and factors that affect them (Darling-Hammond \& Adamsson, 2014; Hämäläinen \& Välijärvi, 2008; Niemi, 2012c; Munthe \& Rogne, 2015). This study may also help find out what are the possible hindrances that may even prevent the development under the framework of $21^{\text {st }}$ century education, referring to already existing studies on skills or abilities (cf. Baer, 2013; Darling-Hammond, 2006a, 2006b; Dede, 2010; Pearlman, 2010; Niemi, 2012c). Finally, this paper will give space for teacher educators globally to reflect on the skills that they would need to enhance in their own curricula to ensure education achievements of the student teachers and their prospective students.

\section{Data and Methods}

The data comprised teacher education programme documents and electronic questionnaire (see Appendix). Six informants participating in this study were the teacher educators who had crucial post in the curricula updates - three from each university. They were asked, first, to report on any major changes in their teacher education programmes in the last three years. The second question focused on the implementation of various $21^{\text {st }}$ century skills, important for teachers, in their programmes. Third, they were asked how research (in its academic meaning of producing new argument-based information) and the so-called "pedagogical thinking" were addressed in the programmes. Pedagogical thinking was defined here as teachers' skills to analyze, assess, criticize, make decisions and facilitate changes in the learning environment for different kinds of learners (Kansanen, 2008; Niemi, 2012b). Finally, the informants were asked about student's feedback on the teacher education studies. The teacher educators who participated in this research remained anonymous as did their students' feedback they were asked to summarize. The data were kept out of reach of any outsiders.

All the data were analyzed and discussed in the light of previous research related to teacher education, paying special attention to $21^{\text {st }}$ century skills (e.g., Niemi, 2002, 2012b, 2012c; Hämäläinen \& Välijärvi, 2008; Kansanen, 2008; Krzywacki, Maaranen, \& Lavonen, 2012; Munthe \& Rogne, 2015). Due to the selected emphasis, some of the studies that focused on the structures of academic teacher education were left aside. Also, 
some studies that analyzed the previous teacher education curricula of UHEL were not included due to the recent changes made in the programmes. Teacher education programme documents were analyzed to provide insights about the key characteristics of the current teacher education programmes in the two selected universities while the questionnaire data from the three informants from each university were triangulated and used to determine the significance and implementation of the $21^{\text {st }}$ century skills in these programmes.

Limitations of this paper may rise from the nature of an updated programme case study approach. The present study concentrated on the recently updated teacher education programmes and contemporary skills and paid minor attention to those previous studies that merely focused on the previous programmes, contents and competencies. On the other hand, this case study article may not reach all the in-depth characteristics outside of the "case". Regardless of this, the findings may serve international audience as a new future-oriented opening and intercultural discussion on eastern and western trends by cases.

\section{3. $21^{\text {st }}$ Century Skills for Teachers}

Using the ideas that Linda Darling-Hammond presented in 2010, this case study named the contemporary $21^{\text {st }}$ century "skill" groups or "abilities" for the data discussion but did not aim to add any ultimate or permanent definitions for them (e.g., Darling-Hammond, 2010a; Pearlman, 2010). Defining the skills precisely in an international context could add confusion in terms of behavioral, analytical, and assessment-related understandings (cf. Dede, 2010; Kansanen, 2008; Pearlman, 2010; Sinlarat et al., 2014). As such the skills and/or abilities discussed in this paper may, or may not, have had a closer description in the mentioned teacher education programmes and the topics this paper dealt with depending on the programme curriculum (cf. Education and training, European Commission, 2013; Darling-Hammond, 2006; Darling-Hammond, 2010a; Dede, 2010; Pearlman, 2010; Niemi, 2012c; see also $21^{\text {st }}$ Century Skills, 2014, p. 2).

Starting with the so-called "thinking skills", this study addressed three types of skills related to thinking - problem solving, analyzing and conceptualizing, and creating, innovating and criticizing (see Education and training, European Commission, 2013; Appendix). Following previous research, this contribution also assumed that teachers should be able to continually learn to address the problems in the practice they encounter and to meet the unpredictable learning needs of their students, these thinking skills are then vital for the teaching profession (e.g., Darling-Hammond, 2005; Kansanen, 2008; cf. Niemi, 2012a, 2012c).

Another umbrella of skills addressed here may be called "transversal skills", seeing them as the abilities that facilitate one's understanding of and participation in the society (McCarthy, 2013; cf. Darling-Hammond, 2010; Kansanen, 2008; Niemi, 2012b). These skills in this contribution included teamwork skills, skills to manage oneself, skills to change (oneself), skills to reflect and improve performance, and learning engagement. These are the qualities that teachers should possess for professional development (e.g., Darling-Hammond, 2010a; DuFour, 2010; Hämäläinen \& Välijärvi, 2008).

Finally, the $21^{\text {st }}$ century "multicultural skills" consist of, for example, abilities to communicate and cross specialist border skills, as well as acceptance of other than expected culture-bound answers and reactions. As DuFour and DuFour (2010) stated, these skills are significant for professional learning communities (cf. Niemi, 2012c).

Why to study such a case and "skill groups"? In a broader perspective, researchers should see, as Hämäläinen and Välijärvi (2008) stated, that the importance of higher education grows along with the dynamics and needs of society, as well as social changes. Consequently, future school teachers ought to be able to produce skills needed in the future society for a "good life" and to utilize the learning opportunities for the changing labour markets, as Hämäläinen and Välijärvi emphasized (cf. Rychen \& Salganik, 2003; Pearlman, 2010; Niemi, 2012a). In sum, future teachers at any level have a crucial role in creating all of these skills and supporting their development in the East and the West. This study mainly highlighted crucial elements in teacher education programmes in order to avoid miscellaneous interpretations in a smaller scale comparison such as study credits of courses, separated from their holistic framework (cf. Kansanen, 2008). 


\section{Findings}

\subsection{Key Characteristics of Teacher Education Studies at UHEL and CU}

The analysis of the teacher education programme documents from the two universities revealed that the main characteristics of the class teacher and subject teacher education programmes at UHEL and CU may be characterized to be different in terms of being institutional and external. The first finding was related "formally" and externally to the length and the completed degree or diploma granted from the studies (Department of Teacher Education, UHEL; Faculty of Education, CU). While it takes five years to complete the undergraduate studies at CU and graduate for a nationally licensed class teacher or subject teacher in Thailand, the Finnish colleagues in UHEL will have the M.A. degree in the same period of time-being as well qualified teachers according to the national statute. On the other hand, the master's degree in education takes additional two years at CU. In a wider teacher education context, both universities seem to rely on their academic programmes and, subsequently, make a difference from various international tendencies (Niemi, 2012a, 2012b; Munthe \& Rogne, 2015; cf. Goodwin, 2010).

The second finding was the course composition and the coherence of the courses in the teacher education programmes. Thai students study a number of courses focusing on the subject matter of their major area in their programmes while their Finnish colleagues in "class teacher" programme focus more on educational studies, classroom analysis, and research from the very beginning. The Finnish "subject" student teachers study content courses in other faculties reaching to the adequate subject matter level to enter the pedagogical studies of the teacher education programme (TEd, UHEL, n.d.; FoE, CU, n.d.; cf. Munthe \& Rogne, 2015; Goodwin, 2010; Niemi, 2012a).

The third essential characteristics arose from the understanding of pedagogy. At $\mathrm{CU}$, the didactic solutions and pedagogy were merely framed and understood to be the methods and methodology of teaching and delivering a certain topic and its content to the students, while at UHEL — and overall in Finland - educational sciences formed a large "umbrella" for general pedagogy and didactic courses, subject-specific didactics, and education for diversities (TEd, UHEL, n.d.; FoE, CU, n.d.; see also Kansanen, 2008; Munthe \& Rogne, 2015; Niemi, 2012b, 2012c; Toom, 2013).

The fourth finding from the document analysis, worth of a closer attention, was the approach for the teacher education curriculum. While UHEL teacher education employed research-based approach for most of the studies, at $\mathrm{CU}$ research was built in as stand-alone courses and as a part of the practice teaching experiences for all the students (TEd, UHEL, n.d.; FoE, CU, n.d.). As Munthe and Rogne (2015) stated, the undergraduate studies research may in some occasion be more teacher-oriented and less student-based. This does not necessarily give adequate further research skills to study the complicated phenomena that a classroom, or any other learning environment, may have (see also Kansanen, 2008; Krokfors et al., 2011; Munthe \& Rogne, 2015; Niemi, 2012c). This academically different approach reflects deeply the societal values and "mission" the education overall may have, as well as teachers' sociodynamic status (Hämäläinen \& Välijärvi, 2008; Kansanen, 2008; Niemi, 2012c; see also Munthe \& Rogne, 2015).

Pointing out some further findings for RQ1, the students' role is seen to be different. Finnish student teachers have been constantly asked to participate in the preparation of the next teacher education curricula updates in boards and teams and have contributed on behalf of the student associations in the curricula development board and Faculty Board meetings (Faculty of Behavioural Sciences, UHEL, n.d.). At CU, the students' role has been more passive and limited to providing feedback only at the course level, which teacher educators then may give significance in their own way (Academic Promotion and Development Division, CU, n.d.).

As it comes to the teaching practice and skill implementation, both universities tended to see a crucial role - meaning and also value - in them. The difference they have arising from the connections between theories and research into practice in any lesson situations during the student teachers' practice teaching. When a Finnish student teacher at UHEL needed to explain his or her pedagogical and didactic solutions before and after the lesson in all the three practice teaching periods on the basis of the educational sciences and theories he or she was implementing, a Thai student teacher may have used and performed methodologies that were located outside of the changing research-based core of their studies and would in most approaches have got suggestions for improvement from the mentoring teacher. In addition, the Thai students needed to have completed their subject matter studies before entering the teaching practice, while their Finnish colleagues did not have to (TEd, UHEL, n.d.; FoE, CU, n.d.; see also Munthe \& Rogne, 2015; Niemi, 2012c; Niemi, Kumpulainen, \& Lipponen, 2014). Some student teachers at UHEL had a sound connection with the classroom action research during their practice period and at CU the student teachers conducted action research as a part of the requirements (TEd, UHEL, n.d.; 
FoE, CU, n.d.; Munthe \& Rogne, 2015; Krokfors et al., 2011; Niemi 2012a; Niemi, Kumpulainen, \& Lipponen, 2014).

Finally, the data showed an external factor to the development of the teacher education programmes. CU teacher education programmes were developed within the national framework and guidelines of the Office of Higher Education Commission (MoE, TH, 2011) and the Teachers Council of Thailand (Teachers Council of Thailand (TCT), 2014). Differently, UHEL programmes were designed by Teacher Education Department and University Teacher Training Schools with no external control other than the Faculty Board confirmation (TEd, UHEL, n.d.).

\subsection{The Roles and Significance of 21st Century Skills-Do They Matter?}

Regarding the enhancement of the $21^{\text {st }}$ century skills in the teacher education programmes in Finland and Thailand, the data showed that at UHEL expected skills gained by the graduates were not described in detail. On the other hand, $\mathrm{CU}$ had a very precise description of the skills the graduating student teachers should have gained during the studies (TEd, UHEL, n.d.; FoE, CU, n.d.; cf. Education and training, European Commission, 2013; also Niemi, 2012a). The descriptions were named to be "learners' desirable characteristics" which appeared to be the same for everyone and were developed within the framework of the Thai Qualifications Framework of Higher Education (TQF: HEd) and Chulalongkorn University's learners' desirable characteristics (FoE, CU, n.d.). These frameworks followed some of the efforts that education researchers have done to define future skills for their graduates (cf. Munthe \& Rogne, 2015; Niemi, 2012a; Pearlman, 2010). However, it seemed that UHEL students and teacher educators did not need such definitions but allowed a range of understanding to be a part of their skills (cf. Darling-Hammond, 2010b; Dede, 2010; Kansanen, 2008; Niemi, 2012a; Pearlman, 2010). This "freedom" of not defining a specific set of skills showed high level of autonomy in the Finnish teacher profession and the characteristics of the studies at UHEL, since elsewhere in European Union the trend seems to be the opposite (Education and training, European Commission, 2013; Kennedy, 2015; Loomis, Rodriguez, \& Tillman, 2008; cf. Niemi, 2012a; see also Niemi, 2012c). From the questionnaires, the overall comments from both universities favor the importance of the ten future skills and were positive that the programmes attempted to enhance those skills.

As the data trend indicated, UHEL and CU teacher educators saw the thinking skill group to be emphasized in many of their courses and also during the teaching practice. The Thai colleagues explained that the student teachers practiced their thinking skills in class activities such as presentations, projects, or simulations as well as during teacher education practice. In other words, inside the Thai definitions of "learner's desirable characteristics" there was an unidentified space and place for the skills to be practised without formal assessment It may be called to be "freedom" inside the "learner's desirable characteristics" definitions. Given this kind of space, the skills then may informally have the similar open space and interpretations as the "unnamed" Finnish skills did (cf. Niemi, 2012a, 2012c). In addition, UHEL student teachers' thinking was enhanced while engaged in their thesis research project (BA and MA studies) (see TEd, UHEL, n.d.). These experience-based and research-based instructional activities have been found in many studies to be supportive for enhancing thinking skills (e.g., Krokfors et al, 2011; Niemi, 2012a; Tirri, 2014). On the other hand, further studies on and assessment of the research that student teachers contribute later in their working life and learning environments would reveal the possible loopholes and problematic teacher-centered "grip" of undergraduate studies research skills (e.g., Sinlarat et al., 2014; cf. Dede 2010; Pearlman, 2010; Niemi, 2012a; Munthe \& Rogne, 2015).

About the enhancement of "transversal skills", the data indicated that UHEL and CU educators also supported the significance of these skills that were enhanced in their programmes. This was a common understanding of all informants. In particular, for teamwork skills the informants reported to have used small group activities to enhance these skills. However, one of CU educators commented that self-discipline was one of the challenges when running group activities. The skills to manage and change oneself were viewed to be significant for the future. However, the teacher educators' viewpoints were different on how they were enhanced in the programmes - either as integral parts in the courses or in research projects. For the ability to reflect and improve performance, both groups of teacher educators viewed it to be critical. The ability to reflect on and improve own (teaching) practice and take responsibility in identifying and meeting professional needs for the teaching profession has also been highlighted as QTS standards for teachers (Training and Development Agency for Schools (TDA), 2007). Last but not least, regarding the abilities to engage in learning, even though all educators saw the importance of learning engagement as a factor for sustainable, lifelong professional development, as mentioned in DuFour and DuFour (2010); they had different comments about the extent to which these skills were enhanced in the programmes. 
In the data, both UHEL and CU informants agreed that multicultural skills were important for their student teachers and were enhanced in many courses. However, the skill to "cross specialist borders" was commented to be inadequately supported in the programmes at UHEL and not at all at CU (TEd, UHEL, n.d.; FoE, CU, n.d.; see also Byram, Grubkova, \& Starkey, 2002; Darling-Hammond, 2010b; Niemi, 2012c).

How were the research skills assessed by the informants? Regarding the enhancement of academic research and new knowledge in their teacher education, UHEL and CU programmes were reflected to enhance research skills for teachers. All the Finnish participants strongly described their programmes as research-based teacher education studies, in which student teachers developed skills to be able to "consume" and "produce" educational research (for more, see Kansanen, 2008; Krokfors et al., 2011; Krzywacki, Maaranen, \& Lavonen, 2012; also Niemi, 2012b; Toom, 2013). Similarly, the data indicated that the Thai programmes integrated research findings in various courses to create links between research and instruction. In promoting research skills, both the Finnish and Thai programmes required their students to conduct research during the course of the programme. In the former case, at least two research projects were required, one during the bachelor's level period and the other the master's thesis whereas in the latter case, action research was required during the practice teaching in the final year of the programme (TEd, UHEL, n.d.; FoE, CU, n.d.; Munthe \& Rogne, 2015; cf. Niemi, 2012a). However, the gained academic research skills with their meanings and learning enhancement input will need further studies. Here it would be enough to say that only a very few, if practically any, teachers who have passed the Master's studies in teacher education and work at schools, have themselves published school or learning environment-related research or academic studies in Finland in the past 25 years.

Since teachers have been regarded to be "decision makers" (Kansanen, 2008; Niemi, 2012b) and the decisions that they make in planning and conducting the lessons affect what and how the students learn (Darling-Hammond et al., 2005), it may be assumed to be vital that teachers have sound theory-based thinking - knowing "how to justify" decisions and actions in the learning process (Adoniou, 2015; cf. Kansanen, 2008). The data from the questionnaires showed that both programmes equipped student teachers with such an important kind of knowledge. The Finnish participants all viewed that pedagogical thinking was very important and was promoted constantly in their programme to ensure that their student teachers become "professionally and pedagogically thinking teachers" for Finnish schools and institutions since Finnish teachers have a strong autonomy in curriculum design and implementation-making decisions in teaching and learning situations. This kind of pedagogical thinking was enhanced in the courses at the master's level as well as during the teaching practice. The same emphasis on pedagogical thinking was reflected by the Thai participants. They stated that the pedagogical thinking was promoted in both the core pedagogical courses and the major area courses; not much elaboration on how it was implemented was provided, however (TEd, UHEL, n.d.; FoE, CU, n.d.; for pedagogical thinking, see e.g., Kansanen, 2008; Niemi, 2012c; Toom, 2013).

What did the data tell about students' feedback? All programmes have received both positive and "needs improvement" feedback. First, in terms of research, the data revealed that the Finnish student teachers seemed to see the value of research but some have commented that the number of research-based courses was too high (cf. Munthe \& Rogne, 2015; Niemi, 2012c). In addition, at the beginning of the pedagogical courses some did not agree with the needs to produce educational research by themselves. On the other hand, the Thai student teachers seemed to agree with the extent to which research findings were integrated in the course content. However, they viewed classroom action research only as a part of their "duties" but not as a tool for teaching improvement (cf. Munthe \& Rogne, 2015). Regarding the pedagogical knowledge and skills, the Finnish student teachers valued these. Irrespective of this, some had requested for more practical skills. In the same vein, the Thai student teachers agreed that the pedagogical thinking and skills promoted in the programme were useful and practical (cf. Darling-Hammond, 2010b; Goodwin, 2010; Pearlman, 2010). The students saw the importance to have such connections between theory and practice but some commented that they did not see clear connections (cf. Niemi, 2012a). The students in the Thai programme, in particular, noted that they did not have much chance to practice in the first three years of the programme. Regarding the subject matter, the Finnish student teachers saw that their programme had already promoted substantial content knowledge in their area. Especially, the secondary teacher education was seen to build expertise on strong subject matter. On the other hand, some had reported needing more interdisciplinary content knowledge. In the Thai programme, different feedback was given by students from different major areas in regard to the content knowledge. For the secondary school student teachers, they felt the content studied was very advanced but inapplicable for the teaching at the basic education level. Whereas the elementary school Thai student teachers reported being not confident because the lack of key concepts in content knowledge. The student teachers in all programmes viewed the teaching practice periods as very important and wanted more. In addition, the Thai student teachers requested to have the practice earlier in 
their programme. Finally, regarding the students' feedback about the skills and attitudes of teacher educators, most informants did not report to have received such feedback. Only one informant said that the students felt some teacher educators were not familiar with school situations, not being able to connect theory and practice.

In conclusion, a comparative study of these Asian and European cases represented by selected Thailand and Finnish big universities is worthwhile since it provides insights beyond the programme details and study credits. The data trends suggest that both the standards-regulated CU teacher education programmes and the UHEL research-based teacher education programmes attempt to prepare their student teachers for future learning by equipping them with the $21^{\text {st }}$ century skills throughout the course of the studies. Second, the programmes were successful in implementing some kind of academic research at the classroom level in their student teachers' experiences and future professional development toolbox. As was previously stated, its practical effectiveness will need further surveys and analysis, however. Third, all teacher education programmes had a strong practical component with a connection between the skills and research in the teaching practice periods. Even though the practice periods at UHEL were shorter, the implementation of the educational studies and research findings into those seemed to be successful. Thai students were also emphasizing the importance of classroom action research in a context that might be more practical than purely academic. One should be reminded; however, those students did not see the importance of the research linkages in their content studies, research, and teaching practices. In-service training plans tailored for the graduated new teachers in close cooperation with their "Alma Mater" university could have a high value on this further development and more fluent implementation of research skills.

\section{Suggestions for Future Development}

The universities contributed here with their teacher education programmes could be discussed separately or together in terms of academic suggestions. It would be more challenging to try to see their cohesive values and development opportunities, however. First, further comparative studies on educational "umbrellas" that seemingly have an important input for the students should be conducted, highlighting also some skill-oriented courses (such as "diversity and multiplicity", UHEL). In addition to this dimension, research on skill development and their implementation should be done in the real working environment: schools and learning organizations by the students and teachers. Also all the tutors of those studies should also have a living connection with schools. In addition, one may ask why it takes five years to get a Bachelor's diploma in teacher education, if no more than action research is required.

Second, teacher education practice periods could be seen as a distinctive way to enhance the future skills and professional development of the students. In particular, those could offer international collaborative research opportunities with mixed data collection methods in the classrooms and other learning environments. Teacher education with enhanced international auditing, skill-supporting approach and peer-coaching would be worth of considering in the light of these outcomes as well.

Finally, it is important to emphasize the importance of the teacher educators' skills that match the needs of a rapidly changing society. Qualitative research is definitely one of them. By no means would the future teachers be just delivering new information, or "consuming research", education for skills to deal with all the surrounding information may create new skills and working styles to be studied further for improved understanding. On the other hand, once the skills are defined, they also too easily freeze into that format-for years. How many studies have been presented by the research-based teacher education professionals in the field? A very few or none. To keep the skills alive and continually enhanced, they should either be studied and practiced all the time or left space enough to grow, change and adapt. These challenges-and skills-will be faced by anyone who is seriously involved in any teacher education programme in any university. Students and their lives only speed up, requesting fresh space and new opportunities for skill development, most of which are not identified yet.

\section{Acknowledgements}

This work was supported by Faculty of Education, Chulalongkorn University, Thailand. 


\section{References}

Academic

$$
\text { Promotion }
$$

and

Development

Division,

CU.

(n.d.). ระบบสารสนเทศเพื่อการบริหารหลักสูตรของจุฬาลงกรณ์มหาวิทยาลัย [Chulalongkorn university curriculum administration system]. academic.chula.ac.th/CU_CAS/m_cas_stu_eval_v2-1.pdf

Retrieved from http://www.

Adoniou, M. (2015). Teacher knowledge: A complex tapestry. Asia-Pacific Journal of Teacher Education, 43(2), 99-116. http://dx.doi.org/10.1080/1359866X.2014.932330

Baer, J. (2013). Teaching for creativity: Domains and divergent thinking, intrinsic motivation, and evaluation. In M. B. Gregerson, H. T. Snyder, \& J. C. Kaufman (Eds.), Teaching creatively and teaching creativity (pp. 175-181). New York, NY: Springer.

Byram, M., Grubkova, B., \& Starkey, H. (2002). Developing the intercultural dimension in language teaching a practical introduction for teachers. Council of Europe: Strasbourg. Retrieved from $\mathrm{http} / / / \mathrm{www} . c o e . i n t / \mathrm{t} / \mathrm{dg} 4 /$ linguistic/source/guide_dimintercult_en.pdf

Darling-Hammond, L. (2006a). Constructing $21^{\text {st }}$ century teacher education. Journal of Teacher Education, 57, 1-15. http://dx.doi.org/10.1177/0022487105285962

Darling-Hammond, L. (2006b). Powerful teacher education: Lessons from exemplary programs. San Francisco, CA: Jossey Bass.

Darling-Hammond, L. (2010a). $21^{\text {st }}$ century skills, abilities and changes of the working life. A presentation at Viikki Teacher Training School, University of Helsinki, Finland.

Darling-Hammond, L. (2010b). New policies for $21^{\text {st }}$ century demands. In J. Bellanca, \& R. Brandt (Eds.), $21^{s t}$ century skills: Rethinking how students learn (pp. 33-49). Bloomington, IN: Solution Tree Press.

Darling-Hammond, L., \& Adamsson, F. (2014). Beyond the bubble test: How performance assessments support $21^{\text {st }}$ century learning. San Francisco, CA: Jossey-Bass, Wiley.

Darling-Hammond, L., Banks, J., Zumwalt, K., Gomez, L., Sherin, M. G., Griesdorn, J., \& Finn, L. (2005). Educational goals and purposes: Developing a curricular vision for teaching. In L. Darling-Hammond, \& J. Bransford (Eds), Preparing teachers for a changing world (pp.169-200). San Francisco, CA: Jossey-Bass, Wiley.

Darling-Hammond, L., \& Lieberman, A. (Eds.). (2012). Teacher education around the world: Changing policies and practices. New York, NY: Routledge.

Dede, C. (2010). Comparing frameworks for $21^{\text {st }}$ century skills. In J. Bellanca, \& R. Brandt (Eds.), $21^{\text {st }}$ century skills: Rethinking how students learn (pp. 51-75). Bloomington, IN: Solution Tree Press.

Department of Teacher Education, University of Helsinki (TEd, UHEL). (n.d.). Class teacher education and subject teacher education. Retrieved from https://weboodi.helsinki.fi/hy/ frame.jsp?Kieli=6\&valittuKieli=6

Education and training, European Commission. (2013). Supporting teacher competence development for better learning outcomes. Retrieved from http://ec.europa.eu/education/policy/school/doc/teachercomp_en.pdf

Faculty of Behavioural Sciences, University of Helsinki. (n.d.). Tiedekuntaneuvoston pöytäkirjat [Minutes of faculty board]. Retrieved from http://www.helsinki.fi/behav/hallinto/tdkneuvosto/2013/index.htm

Faculty of Education, Chulalongkorn University (FoE, CU). (n.d.). หลักสูตร. [Curriculum]. Retrieved from http://portal.edu.chula.ac.th/academic/view.php?Page=1243999546337277

Goodwin, A. L. (2010). Globalization and the preparation of quality teachers: Rethinking knowledge domains for teaching. Teaching Education, 21, 19-32. http://dx.doi.org/10.1080/10476210903466901

Hämäläinen, K., \& Välijärvi, J. (2008). Challenges for education. In J. Loima (Ed.), Facing the future: Developing teacher education (pp. 13-47). Helsinki, Finland: Helsinki University Press.

Kansanen, P. (2008). Distinctive highlights of Finnish teacher education. In J. Loima (Ed.), Facing the Future: Developing Teacher Education (pp. 48-68). Helsinki, Finland: Helsinki University Press.

Kennedy, A. (2015). What do professional learning policies say about purposes of teacher education? $\begin{array}{lllll}\text { Asia-Pacific Journal of Teacher } & \text { Education, } & 43(3), & \end{array}$ http://dx.doi.org/10.1080/1359866X.2014.940279 
Krokfors, L., Kynäslahti, H., Stenberg, K., Toom, A., Maaranen, K., Jyrhämä, R., \& Kansanen, P. (2011). Investigating Finnish teacher educators' views on research-based teacher education. Teaching Education, 22(1), 1-13. http://dx.doi.org/10.1080/10476210.2010.542559

Krzywacki, H., Maaranen, K., \& Lavonen, J. (2012). Confronting the educational challenges of the future: Finnish teacher education promoting teachers' pedagogical thinking. In O. S. Tan (Ed.), Teacher education frontiers: International perspectives on policy and practice for building new teacher competencies ( $\mathrm{pp}$. 283-305). Singapore: Cengage Learning Asia Pte Ltd.

Loomis, S., Rodriguez, J., \& Tillman, R. (2008). Developing into similarity: Global teacher education in the twenty-first century. European Journal of Teacher Education, 31(3), 233-245. http://dx.doi.org/10.1080/02619760802208288

McCarthy, R. (2013). Mapping transversal/non-cognitive skills in education [News from UNESCO Bangkok]. Retrieved from http://www.unescobkk.org/ru/education/news/article/mapping-transversalnon-cognitiveskills-in-education/

Ministry of Education, Thailand (MoE, TH). (2005). ประกาศกระทรวงศึกษาธิการ เรื่อง แนวทางการบริหารเกณฑ์มาตรฐาน หลักสูตรระดับอุดมศึกษา พ.ศ. เ๕๕๘ [Notification of Ministry of Education. Re: Guidelines for management of higher education programme standards B.E. 2548]. Retrieved from http://www.mua.go.th/users/he-commission/doc/law/ministry $\% 201$ aw $/ 16 \% 20$ manage $\% 20$ standard $\%$ 202548.pdf

Ministry of Education, Thailand (MoE, TH). (2011). ประกาศกระทรวงศึกษาธิการ เรื่อง มาตรฐานคุณวุฒิระดับปริญญาตรี สาขาครุศาสตร์และสาขาศึกษาศาสตร์ (หลักสูตร 5 ปี) [Notification of Ministry of Education. Re: Qualifications framework for bachelor's degree in education (5-year programme)]. Retrieved from http://www.mua.go.th/users/tqf-hed/news/FilesNews/FilesNews6/ education5year_m1.pdf

Ministry of Education and Culture, Finland (MoEC, FI). (2011). Universities Act 558/2009 (As amended up to 315/2011). Retrieved from http://www.finlex.fi/fi/laki/kaannokset/2009/en20090558.pdf

Munthe, E., \& Rogne, M. (2015). Research based teacher education. Teaching and Teacher Education, 46, 17-24. http://dx.doi.org/10.1016/j.tate.2014.10.006

Niemi, H. (2002). Active learning-A cultural change needed in teacher education and schools. Teaching and Teacher Education, 18, 763-780. http://dx.doi.org/10.1016/S0742-051X(02)00042-2

Niemi, H. (2012a). Relationships of teachers' professional competences, active learning, and research studies in teacher education in Finland. Reflection Education, 8(2), 23-44. Retrieved from http://www.reflectingeducation.net/index.php/reflecting/article/view/114/118

Niemi, H. (2012b). Teacher education for high quality professionals: An analysis from the Finnish perspectives. In O. S. Tan (Ed.), Teacher education frontiers: International perspectives on policy and practice for building new teacher competencies (pp. 43-69). Singapore: Cengage Learning Asia Pte Ltd.

Niemi, H. (2012c). The Societal factors contributing to education and schooling in Finland. In H. Niemi, A. Toom, \& A. Kallioniemi (Eds.), Miracle of education: The principles and practices of teaching and learning in Finnish schools (pp. 19-38). Rotterdam, the Netherlands: Sense Publishers. http://dx.doi.org/10.1007/978-94-6091-811-7_2

Niemi, R., Kumpulainen, K., \& Lipponen, L. (2014). Pupils' documentation enlightening teacher's practical theory and pedagogical actions. Educational Action Research. http://dx.doi.org/10.1080/09650792.2014.942334

Niemi, H., \& Lavonen, J. (2012). Evaluation for improvements in Finnish teacher education. In J. Harford, B. Hudson, \& H. Niemi (Eds.), Quality assurance and teacher education (pp. 159-185). Bern, Switzerland: Peter Lang.

Office of Higher Education Commission (OHEC), Thailand. (2009). Thai qualifications framework for higher education. Retrieved from http://www.mua.go.th/users/tqf-hed/

Pearlman, B. (2010). Designing new learning environments to support $21^{\text {st }}$ century skills. In J. Bellanca, \& R. Brandt (Eds.), $21^{\text {st }}$ century skills: Rethinking how students learn (pp. 118-127). Bloomington, IN: Solution Tree Press. 
Rychen, D. S., \& Salganik, L. H. (Eds.). (2003). Key competencies for a successful life and a well-functioning society. Cambridge, MA: Hogrefe \& Huber.

Sinlarat, P., Areesophonpichet, S., Siritho, S., \& Poolsawat, K. (2014). ทิศทาง แนวโน้ม และคุณลักษณะบัณฑิตอุดมศึกษา [Trends, directions, and graduate student attributes in higher education]. In การจัดทำข้อเสนอมาตรฐานการอุดมศึกษาและเกณฑ์มาตรฐานหลักสูตรระดับอุดมศึกษา [New criteria of curriculum standards for Thai higher education]. Bangkok, Thailand: Office of Higher Education Commission.

Tan, O. S. (Ed.). (2012). Teacher education frontiers: International perspectives on policy and practice for building new teacher competencies. Singapore: Cengage Learning Asia Pte Ltd.

Teachers Council of Thailand (TCT). (2014). ประกาศคุรุสภา เรื่อง การรับรองปริญญาและประกาศนียบัตรทางการศึกษาเพื่อการประกอบวิชาชีพ พ.ศ. ๒๕๕ฒ [Notification of the teachers council of Thailand. Re: Accreditation of educational degrees and certificates for professional practices B.E. 2557]. Retrieved from http://www.ksp.or.th/ksp2013/ home/index.php

Thongthew, S. (2014). Changes in teacher education in Thailand 1978-2014. Journal of Education for Teaching: International Research and Pedagogy, 40(5), 543-550.

Tirri, K. (2014). The last 40 years in Finnish teacher education. Journal of Education for Teaching: International Research and Pedagogy, 40(5), 600-609. http://dx.doi.org/10.1080/02607476.2014.956545

Toom, A. (2013, March 19). Research-based teacher education: Finnish perspective [Powerpoint Presentation]. Retrieved from http://ffl.uis.no/getfile.php/F\%C3\%B81 gegruppen\%20for\%201\%C3\%A6rerutdanningen\%20\%28FFL\%29/ppPresentasjon\%20Toom_Kautokeino_ March_2013\%281\%29.pdf

Training and Development Agency for Schools (TDA). (2007). Professional standards for teachers. Retrieved from http://www.tda.gov.uk

\section{Appendix}

A Questionnaire for a Teacher Educator/Comparative teacher education research, Fall 2014

Dear receiver,

An international research group will study similarities and differences in teacher education curricula in two universities: University of Helsinki and Chulalongkorn university, Thailand. Similar studies have been done previously (see, Krzywacki, Maaranen, \& Lavonen, 2012) but this one will reflect the skills in the light of $21^{\text {st }}$ century learning environment theories and teacher educators' skills as well.

\section{A. Background information. You will be anonymous in terms of identity and position.}

Education Experience in years

Responsibilities in teacher education

University

B. Kindly answer the following questions into the space between.

(1). What kind of major changes your teacher education (or teacher education curriculum) has had in the last three years?

(2). How would you characterize the following skills (by Professor Darling-Hammond, US) and their implementation in your teacher education (curriculum)? Please, describe in brief, for example, from "crucial in many courses" to "not existing", or as you would like to say it.

Ability to communicate

Ability to change (oneself)

Ability to work in teams

Ability to solve problems 
Ability to analyze and conceptualize

Ability to reflect and improve performance

Ability to manage oneself

Ability to create, innovate and criticize

Ability to engage in learning new things at all times

Ability to cross specialist borders

(3). How would you describe the emphasis that research and, on the other hand, pedagogical thinking have in your teacher education (curricula)?

(4). What kind of feedback students have given in the last three years of following topics or areas?

Research and research-based education

Pedagogical thinking and skills

Combining theory and practice

Subject matter/content knowledge

Practice/training periods

Teacher educators' own skills and attitudes

(5). Is there anything else you would like to emphasize/comment/present for the research group?

Thanks for participating to our research. Kindly send this paper as an attachment to jyrki.loima@gmail.com

\section{Copyrights}

Copyright for this article is retained by the author(s), with first publication rights granted to the journal.

This is an open-access article distributed under the terms and conditions of the Creative Commons Attribution license (http://creativecommons.org/licenses/by/3.0/). 